\title{
«Celui qui ouvre une porte d'école, ferme une prison » : The importance of school as a forge of lifelong learning habits
}

\author{
Stephen Roche
}

Published online: 21 January 2014

(C) Springer Science+Business Media Dordrecht and UNESCO Institute for Lifelong Learning 2014

The current issue of the International Review of Education (IRE) is mostly concerned with schools, their students and teachers. It is not that we have decided to change the course we announced in our last general issue (59:2, July 2013). On the contrary, having published two very well-received special issues in the meantime on Lifelong Learning and Learning Cities - we are more confident than ever that the future of our journal lies in a focus on education and learning as lifelong endeavours. However, we also recognise that primary and secondary schools are where most people's learning habits are formed. Failure to enter or remain in school - both by students and teachers - is therefore a cause of great concern.

We begin this issue with an article (in French) by three Canadian researchers Thierry Karsenti, Simon Collin and Gabriel Dumouchel - that seeks to get to the bottom of what the influential American magazine The Atlantic recently called "one of teaching's most significant problems" - the high dropout rates among teachers in North America. In the United States of America, for example, almost half a million teachers leave their schools each year. Only 16 per cent of this so-called "teacher attrition" is due to retirement; the remainder is the result of teachers transferring between schools or leaving the profession entirely (Alliance for Excellent Education 2008). So far, growing numbers of new entrants to the profession - perhaps spurred by an anaemic job market - have prevented the problem turning into a crisis. But for how long can a profession withstand such a talent drain? And what impact does it have on the morale of those who remain? The authors embark on a comprehensive analysis of 69 research papers published over the last two decades. Their primary aim is to identify recurring factors in the literature on teacher attrition, particularly of new teachers. They also consider the cost of high teacher turnover, and its longterm implications, both in North America and internationally.

\footnotetext{
S. Roche $(\square)$

UNESCO Institute for Lifelong Learning, Hamburg, Germany

e-mail: s.roche@unesco.org
} 
The authors identify three main sets of factors affecting teacher attrition: those related to the occupation, to the teacher and to the social environment. They distil from the literature three principal ways of stemming the tide: greater confrontation with the reality of the school environment during initial teacher education; policies and programmes that support teachers in the early years of their careers; and a departure from the "sink or swim" practice, whereby new teachers are often placed in the most difficult schools. Moreover, the authors propose a re-consideration of the process by which new teachers enter the profession, and suggest merging the training phase with teachers' insertion into the working environment. This would allow "the responsibility for the guidance of new teachers to be transferred in a gradual and concerted manner from the universities to the schools" (la responsabilité de l'accompagnement de l'enseignant débutant est transmise progressivement et de façon concertée des établissements universitaires aux établissements scolaires). The authors emphasise that this re-conceptualisation "...will require both political will and the necessary financial means to realise it" (...ce qui nécessite à la fois une volonté politique et les moyens financiers nécessaires à sa concrétisation).

Teachers are not the only ones dropping out of school. Many students, both in developing and developed countries, leave school early, leading, frequently, to underachievement in later life, and contributing to more serious problems, such as unemployment, addiction and crime (Brunello and De Paola 2013). The European Union, in its growth strategy for the current decade (Europe 2020 strategy) has set itself the target "to lift at least 20 million people out of poverty and social exclusion in the next decade" (European Commission 2010). A major priority within this strategy is to tackle early school leaving (ESL): "The Europe 2020 strategy therefore includes the headline target to reduce early school leaving to less than $10 \%$ by 2020 , from $14.4 \%$ in 2009 " (ibid.). However, in a community as large and diverse as the European Union, unified targets are highly problematic and unified strategies nearly impossible. The authors of our third article - Xavier Lastra-Bravo, Alfredo Tolón-Becerra and José Salinas-Andújar - take on this problem. They propose a nonlinear distribution method to transfer the EU-wide headline target to individual national targets. They advance from the premise that "the reduction in the population of early school leavers should not be linear for all Member States". They contend, rather, that "the European targets must be transferred to national and regional policies by setting territorial targets and adopting measures that include national and regional differences". Rather than each country trying to reach the $10 \%$ target, the authors believe that "each of the Member States should have a target based on its own characteristics, so that together the 27 Member States reach a maximum ESL rate in 2020 of no more than 10 per cent".

This study proposes weighted modulation of the reduction coefficients for the population of early school leavers (those aged 18-24 who have not completed secondary education, nor have enrolled in any further education or training), based on four indicators: ESL rate; youth unemployment rate; public spending on education as a percentage of gross domestic product (GDP) or of total public spending; and expenditure on schools per student. Using this approach, the authors propose nine possible scenarios for ESL reduction, applicable to three groups of 
countries: the whole EU up to June 2013 (EU27); EU Member States that joined before 30 April 2004 (EU15); and EU Member States that joined after 30 April 2004 (EU12). Having introduced the method, the study goes on to apply it to the available data for the period 2000-2010. It concludes with a brief review of policy approaches to reducing ESL.

From early school leaving in Europe, we turn to late school entry in Africa. Despite the apparent difference between these two topics, we see, on closer inspection, many of the same factors at work: household wealth and stability; the educational level of parents; and the social milieu. Moses Ngware, Moses Oketch, Alex Ezeh and Maurice Mutisya discuss all of these factors within a study of the impact of the Kenyan government's free primary education (FPE) policy introduced in 2003 - on school entry age. Their results and conclusions have great relevance for sub-Saharan Africa, where FPE was introduced in nine different countries between 1994 and 2003. FPE is also regarded as one of the key instruments for achieving universal primary education, the second of the Millennium Development Goals. This article shows, however, that free primary education does not necessarily lead to universal primary education. To assess the impact of FPE on school entry age in Kenya, the authors propose a binary probit model. Their purpose was to determine whether the introduction of FPE affected the age at which children entered school in Grade 1. Overall, the findings show that FPE has reduced late entry to first grade, and confirms what other studies in developing countries have found - that reducing cost barriers to schooling also reduces late school entry. They demonstrate that, even if the intention of the government is to achieve universal primary education, due to the different contexts within which school-aged children live, equity cannot be achieved with supply-side interventions alone.

The authors therefore call for demand-driven policies that target younger schoolaged children whose barriers to timely enrolment are not eliminated by removing the direct costs of schooling. One way of minimising late school entry by younger children from vulnerable households is to intervene in ways that reduce poverty and eliminate child labour, such as conditional cash transfers. The paper reveals both the successes and the limitations of free primary education in a developing African nation; while FPE has led to a reduction in late school entry, the positive effects have been mitigated by the contextual factors mentioned above.

The final article in this issue deals with one of the most contentious issues in curriculum development: the teaching of history. History textbooks are frequently the topic of heated public debate, from local school boards up to national parliaments. Yet, according to James Loewen, who has conducted extensive research on how history is taught in American schools, students also consistently rate history as their most boring and least relevant subject (Loewen 1995). Muddying the water further is the fact that history books regularly top non-fiction bestseller lists. How can a single subject be loathed by students, loved by adult readers, and feared by politicians? In a highly engaging article, Esther Yogev first considers how history education "is often caught in a vice of hegemonic politicisation that veils its true ideological positions". To counter this, she advocates the fostering of "a political-critical dimension in the context of history education.” Citing Jürgen Habermas, Hans-Georg Gadamer, Peter Seixas and Jörn 
Rüsen, she proposes the implementation of a "pedagogy of subversion" in education. She explains this as "teaching practices ... designed to enable students of history to develop critical historical thinking, identify interests and centres of power that influence the shaping of their consciousness in the present and associate the interpretation of past events with the contexts of their present life". Adolescent resistance to education can thus be harnessed as a tool, providing "an object for the student to contend with personally as part of his or her maturation and individuation process". The desired outcome is the development of an historical consciousness that enhances autonomous thinking, reflective skills and empathetic capabilities among young people. These capabilities, in turn, form the bedrock of democratic citizenship. This article proposes an approach to curriculum and its implementation that has relevance far beyond history class.

\section{References}

Alliance for Excellent Education. (2008). What keeps good teachers in the classroom? Understanding and reducing teacher turnover. Washington, DC: Alliance for Excellent Education.

Brunello, J., \& De Paola, M. (2013). The costs of early school leaving in Europe. EENEE Analytical Report No. 17. Prepared for the European Commission. Munich: European Expert Network on Economics of Education (EENEE).

European Commission. (2010). EUROPE 2020: A strategy for smart, sustainable and inclusive growth. Communication from the Commission COM(2010) 2020 final. Brussels: EC.

Loewen, J. W. (1995). Lies my teacher told me: Everything your American history textbook got wrong. New York: Simon \& Schuster.

Riggs, L. (2013). Why do teachers quit? And why do they stay? The Atlantic, October 18. Accessed 9 December 2013, from http://www.theatlantic.com/education/archive/2013/10/why-do-teachers-quit/ $280699 /$. 